\title{
Electronically tunable current mode biquad filter based on single VDTA and grounded passive elements
}

\author{
Chandra Shankar $^{\# 1}$, Sajai Vir Singh ${ }^{* 2}$ \\ \# Dept. of Electronics Engineering, \\ JSS Academy of Technical Education Noida, 201301, INDIA \\ * Dept. of Electronics and Communication Engineering \\ Jaypee Institute of Information Technology, Noida, 201304, INDIA \\ 1porwalchandra@gmail.com \\ 2sajaivir75@gmail.com
}

\begin{abstract}
This paper presents a new filter structure based on only single voltage differencing transconductance amplifier (VDTA) and three grounded passive elements and has capability to low pass (LP), band pass (BP), high pass (HP), band reject (BR) and all pass (AP) biquad filtering functions at an explicit current output by the use of appropriate selection of three current input signals. Hence, it is fully integrable, canonical in nature and universal current-mode (CM) biquad. Besides it, the proposed filter also enjoys few more desirable features such as low active and passive sensitivities, low power consumption and orthogonal tunability of pole frequency and quality factor by electronic means. The presented filter is simulated using PSPICE in $0.18 \mu \mathrm{m}$ CMOS process.
\end{abstract}

Keyword- VDTA, Biquad, Tunable filter, Current-mode

\section{INTRODUCTION}

In last several decades, analogue circuit designers have shown significant research attention on study and synthesis of CM biquad filters based on various high performances CM active elements and became one of the emerging topics in current research. Thus, applications, implementation and benefits of different CM active filters based on various active elements have been discussed and studied intensively in the literature [1-25]. However, with a view to being adaptable towards low cost, low power, simplicity and area saving of the circuits, it is beneficial to realize CM biquad filter using single active element. Thus, in recent years a number of CM biquad filter using single active elements are reported in the literature [9-24] employing CCII[18,23], FDCCII [11,24], DVCC[12], CCCII [20], CFTA [9,15,21], VDTA [10,13,22], CDTA[14,17] CCTA [16], CCCCTA [19], etc., whose features are compared and summarized in Table 1. After comparative study of the circuits endorsed in Table I, it has been concluded that these reported circuits unfortunately, suffer from at least one of the following disadvantages.

i. Does not realize all the five filtering functions [9-19].

ii. Need of inverted current input to realize AP function, which further required additional active elements to obtain inverted current signal [20-22].

iii. Requires one or more floating passive element to realize filtering function in current-mode [9, 14, 15, 17-18, 20-21, 23].

iv. Lack of electronic tunability [11, 12 15, 18, 21, 23-24].

v. Excessive number of passive elements[11-12,14,16,18,23-24] 
TABLE I. COMPARISON OF DIFFERENT SINGLE ACTIVE ELEMENT BASED CM FILTERS WITH PROPOSED CM FILTER CIRCUIT

\begin{tabular}{|c|c|c|c|c|c|c|c|c|c|c|c|c|c|c|c|c|c|}
\hline $\begin{array}{c}\text { Ref. } \\
\begin{array}{c}\text { Attribu } \\
\text { tes }\end{array}\end{array}$ & [9] & {$[10]$} & [11] & [12] & [13] & [14] & [15] & {$[16]$} & [17] & [18] & [19] & {$[20]$} & [21] & {$[22]$} & [23] & [24] & $\begin{array}{c}\text { Propo } \\
\text { sed }\end{array}$ \\
\hline $\begin{array}{l}\text { Active } \\
\text { Elemen } \\
\text { t used }\end{array}$ & $\begin{array}{c}\mathrm{M} \\
\mathrm{O} \\
\mathrm{CF} \\
\mathrm{TA} \\
\end{array}$ & $\begin{array}{l}\text { VD } \\
\text { TA }\end{array}$ & $\begin{array}{c}\text { FDCCI } \\
\text { I }\end{array}$ & DVCC & $\begin{array}{l}\text { VD } \\
\text { TA }\end{array}$ & $\begin{array}{c}\text { DO- } \\
\text { CDTA }\end{array}$ & CFTA & $\begin{array}{c}\mathrm{CCT} \\
\mathrm{A}\end{array}$ & CDTA & $\begin{array}{c}\text { CCI } \\
\text { I }\end{array}$ & $\begin{array}{c}\mathrm{CCCC} \\
\mathrm{TA}\end{array}$ & $\begin{array}{c}\mathrm{CCC} \\
\text { II }\end{array}$ & CFTA & $\begin{array}{c}\text { VDT } \\
\mathrm{A}\end{array}$ & CCII & $\begin{array}{c}\text { FD } \\
\text { CCII }\end{array}$ & VDTA \\
\hline $\begin{array}{c}\text { No. \& } \\
\text { type } \\
\text { of } \\
\text { Passive } \\
\text { Elemen } \\
\text { ts } \\
\text { employ } \\
\text { ed }\end{array}$ & $\begin{array}{c}1 \mathrm{R} \\
+ \\
2 \mathrm{C}\end{array}$ & $2 \mathrm{C}$ & $2 \mathrm{R}+2 \mathrm{C}$ & $2 \mathrm{R}+2 \mathrm{C}$ & $\begin{array}{l}1 \mathrm{R} \\
+2 \\
\mathrm{C}\end{array}$ & $2 \mathrm{R}+2 \mathrm{C}$ & $\begin{array}{c}1 \mathrm{R}+ \\
2 \mathrm{C}\end{array}$ & $\begin{array}{c}2 \mathrm{C}+ \\
2 \mathrm{R}\end{array}$ & $\begin{array}{c}1 \mathrm{R}+ \\
2 \mathrm{C}\end{array}$ & $\begin{array}{c}2 \mathrm{R} \\
+ \\
2 \mathrm{C}\end{array}$ & $2 \mathrm{C}$ & $\begin{array}{c}1 \mathrm{R}+2 \\
\mathrm{C}\end{array}$ & $1 \mathrm{R}+2 \mathrm{C}$ & $2 \mathrm{C}$ & $\begin{array}{c}2 \mathrm{R}+2 \\
\mathrm{C}\end{array}$ & $2 \mathrm{R}+2 \mathrm{C}$ & $1 \mathrm{R}+2 \mathrm{C}$ \\
\hline $\begin{array}{c}\text { Filterin } \\
\text { g } \\
\text { Functi } \\
\text { ons } \\
\text { Realize } \\
\text { d }\end{array}$ & $\begin{array}{l}\text { LP, } \\
\text { BP, } \\
\text { HP }\end{array}$ & $\begin{array}{l}\text { LP, } \\
\text { BP, } \\
\text { HP }\end{array}$ & $\begin{array}{l}\text { LP,BP } \\
\text { or } \\
\text { HP,BP }\end{array}$ & $\begin{array}{c}\text { LP,BP, } \\
\text { HP }\end{array}$ & $\begin{array}{l}\text { LP, } \\
\text { BP, } \\
\text { HP }\end{array}$ & $\begin{array}{c}\text { LP,BP, } \\
\text { HP }\end{array}$ & $\begin{array}{c}\text { LP,BP, } \\
\text { HP }\end{array}$ & $\begin{array}{l}\text { LP, } \\
\text { BP, } \\
\text { HP }\end{array}$ & $\begin{array}{c}\text { LP,BP, } \\
\text { HP }\end{array}$ & $\begin{array}{l}\text { LP, } \\
\text { BP }\end{array}$ & $\begin{array}{c}\text { LP,BP, } \\
\text { HP }\end{array}$ & $\begin{array}{l}\text { LP, } \\
\text { BP, } \\
\mathrm{HP}, \\
\mathrm{BR}, \\
\mathrm{AP}\end{array}$ & $\begin{array}{l}\text { LP, } \\
\text { BP, } \\
\text { HP, } \\
\text { BR, } \\
\text { AP }\end{array}$ & $\begin{array}{l}\text { LP, } \\
\mathrm{BP}, \\
\mathrm{HP}, \\
\mathrm{BR}, \\
\mathrm{AP}\end{array}$ & $\begin{array}{l}\text { LP, } \\
\text { BP, } \\
\text { HP, } \\
\text { BR, } \\
\text { AP }\end{array}$ & $\begin{array}{l}\text { LP, } \\
\mathrm{BP}, \\
\mathrm{HP}, \\
\mathrm{BR}, \\
\mathrm{AP}\end{array}$ & $\begin{array}{l}\text { LP, } \\
\text { BP, } \\
\text { HP, } \\
\text { BR, } \\
\text { AP }\end{array}$ \\
\hline $\begin{array}{l}\text { Floatin } \\
\text { g } \\
\text { Passive } \\
\text { Elemen } \\
\text { ts used }\end{array}$ & $1 \mathrm{R}$ & $\begin{array}{l}\text { No } \\
\text { ne }\end{array}$ & None & None & $\begin{array}{l}\text { No } \\
\text { ne }\end{array}$ & $2 \mathrm{R}$ & $1 \mathrm{R}$ & None & $1 \mathrm{R}$ & $1 \mathrm{R}$ & None & $1 \mathrm{R}$ & $1 \mathrm{R}$ & None & $1 \mathrm{C}$ & None & None \\
\hline $\begin{array}{l}\text { Electro } \\
\text { nic } \\
\text { Tunabi } \\
\text { lity of } \\
\omega_{0} \text { and } \\
Q \\
Q\end{array}$ & $\begin{array}{c}\text { YE } \\
\text { S }\end{array}$ & $\begin{array}{c}\text { YE } \\
\text { S }\end{array}$ & NO & NO & $\begin{array}{c}\mathrm{YE} \\
\mathrm{S}\end{array}$ & YES & $\mathrm{NO}$ & YES & YES & NO & YES & YES & NO & YES & NO & NO & YES \\
\hline $\begin{array}{l}\text { Design } \\
\text { ed Pole } \\
\text { Freque } \\
\text { ncy }\end{array}$ & $\begin{array}{c}1.3 \\
5 \\
\mathrm{M} \\
\mathrm{Hz}\end{array}$ & $\begin{array}{c}3.0 \\
3 \\
\mathrm{MH} \\
\mathrm{z}\end{array}$ & $\begin{array}{c}10 \\
\mathrm{MHz}\end{array}$ & $\begin{array}{c}9.7 \\
\mathrm{MHz}\end{array}$ & NA & NA & $\begin{array}{c}159 \\
\mathrm{KHz}\end{array}$ & $\begin{array}{c}1 \\
\mathrm{MHz}\end{array}$ & $\begin{array}{c}10 \\
\mathrm{MHz}\end{array}$ & NA & $\begin{array}{c}572 \\
\mathrm{KHz}\end{array}$ & $\begin{array}{c}1 \\
\mathrm{MHz}\end{array}$ & $\begin{array}{c}1.12 \\
\mathrm{MHz}\end{array}$ & $\begin{array}{c}3 \\
\mathrm{MHz}\end{array}$ & NA & $\begin{array}{l}1.59 \\
\mathrm{MHz}\end{array}$ & $\begin{array}{l}3.93 \\
\mathrm{MHz}\end{array}$ \\
\hline $\begin{array}{l}\text { Inverte } \\
\text { d Input } \\
\text { require } \\
\text { d }\end{array}$ & $\mathrm{NO}$ & $\mathrm{NO}$ & NO & $\mathrm{NO}$ & NO & NO & $\mathrm{NO}$ & $\mathrm{NO}$ & $\mathrm{NO}$ & NO & NO & YES & YES & YES & NO & NO & NO \\
\hline
\end{tabular}

Keeping above points in the mind, this study proposes a new current-mode filter by the use of only single active element and has number of attractive features which are (i) realizes all five standard filtering functions in CM without needing inverted current input signal(s), (ii) use of only grounded passive elements which is ideally suited for IC fabrication, (iii) high output impedance for current filtering response(s), (iv) providing low active and passive sensitivities, (v) orthogonal current control of the pole frequency and quality factor.

\section{VDTA DESCRIPTION}

The VDTA is relatively new element and has been popularized and frequently used in designing of analog filters $[10,13,22,26-29]$ in last few years. The symbolic diagram of VDTA is shown in Fig.1. The characteristic equation defining the relationship between various terminals voltage current of VDTA can be described as.

$$
\left[\begin{array}{c}
I_{Z+} \\
I_{Z-} \\
I_{X \pm}
\end{array}\right]=\left[\begin{array}{ccc}
g_{m 1} & -g_{m 1} & 0 \\
-g_{m 1} & g_{m 1} & 0 \\
0 & 0 & \pm g_{m 2}
\end{array}\right]\left[\begin{array}{l}
V_{P} \\
V_{N} \\
V_{Z}
\end{array}\right]
$$

Here, $g_{\mathrm{m} 1}$ and $g_{\mathrm{m} 2}$ are trans-conductance parameters of VDTA which depending on the biasing current $I_{B I}$ and $I_{B 2}$ of VDTA, respectively. The CMOS implemented model of VDTA as per Fig. 1 is depicted in Fig.2. The expression of $g_{m 1}$ and $g_{m 2}$ in term of $\mathrm{I}_{\mathrm{B} 1}$ and $\mathrm{I}_{\mathrm{B} 2}$, respectively, for CMOS implemented model of VDTA [27] shown in Fig. 2 can be formulated as.

$$
\begin{aligned}
& g_{m 1}=\sqrt{I_{B 1} \mu_{n} C_{o x}\left(\frac{W}{L}\right)_{M 1, M 2}} \\
& g_{m 2}=\sqrt{I_{B 2} \mu_{n} C_{o x}\left(\frac{W}{L}\right)_{M 17, M 18}}
\end{aligned}
$$




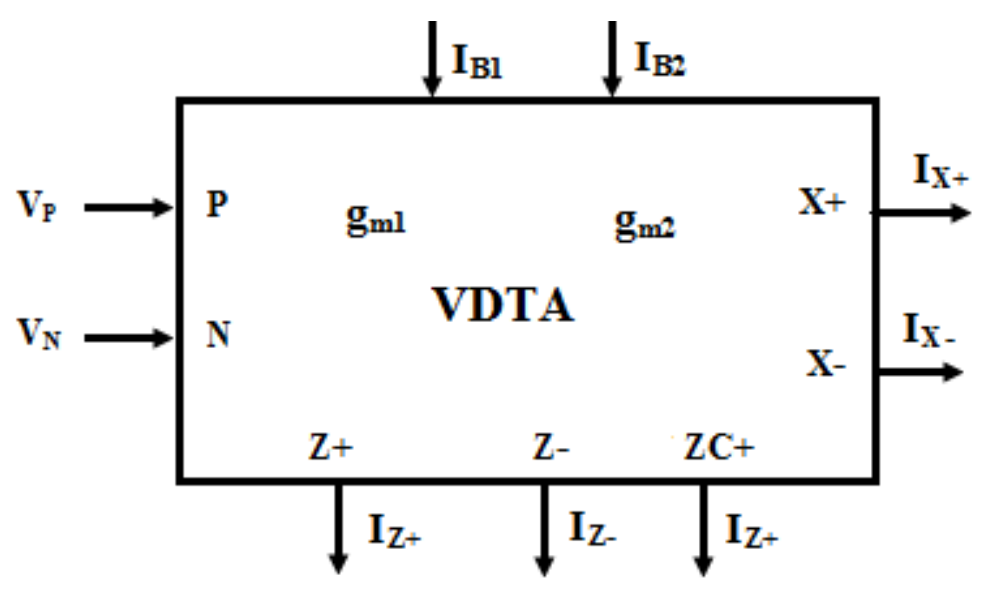

Fig.1:.Symbolic diagram of VDTA

Where $\mu_{n}$ is the mobility of the electron and $C_{\mathrm{ox}}$ is the gate- capacitance per unit area of oxide layer used in NMOS. (W/L) $)_{\mathrm{M} 1, \mathrm{M} 2}$ and $(\mathrm{W} / \mathrm{L})_{\mathrm{M} 17, \mathrm{M} 18}$ are the aspect ratio of $\mathrm{M}_{1}, \mathrm{M}_{2}$ and $\mathrm{M}_{17}, \mathrm{M}_{18} \mathrm{NMOS}$ transistor pairs, respectively.

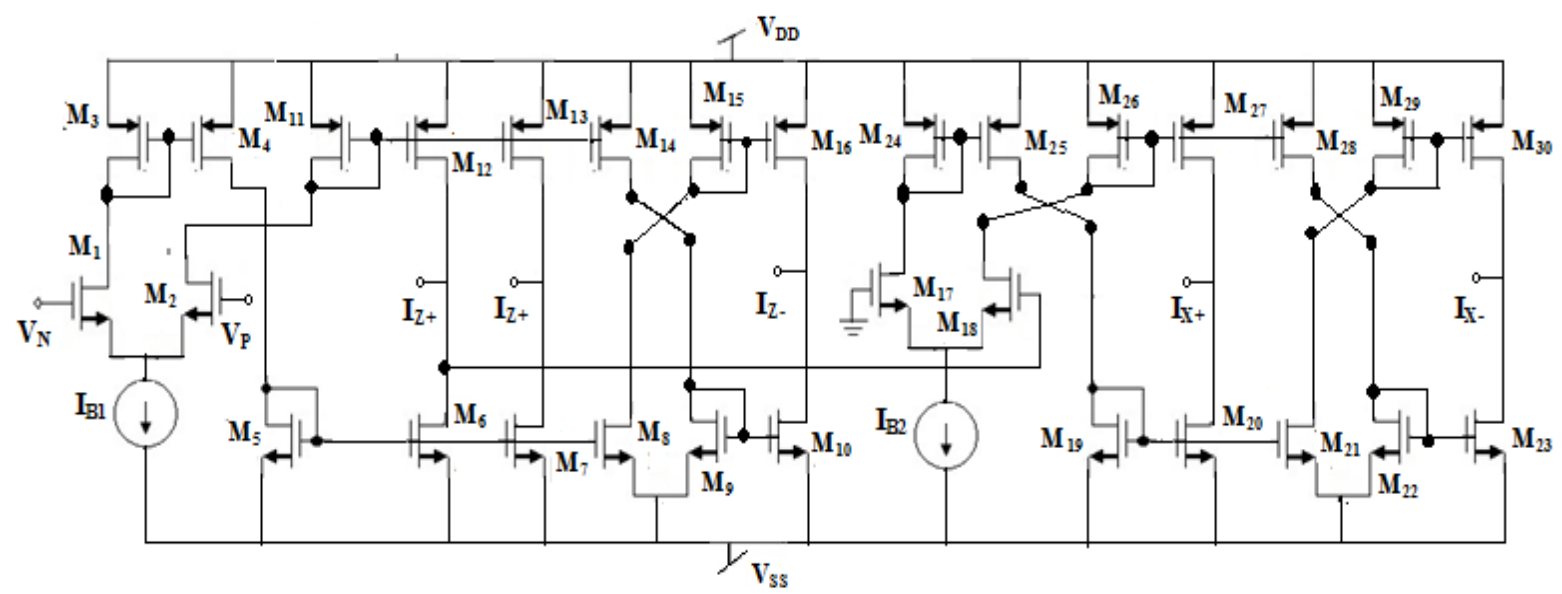

Fig.2. CMOS implemented model of VDTA

\section{PROPOSED CURRENT MODE BIQUAD FILTER}

The proposed CM biquad with three current input signals $\left(\mathrm{I}_{1}, \mathrm{I}_{2}\right.$ and $\left.\mathrm{I}_{3}\right)$ and single current output signal $\left(\mathrm{I}_{\text {out }}\right)$ is shown in Fig.3 which consists of single VDTA, one grounded resistor $(\mathrm{R})$ and two grounded capacitors $\left(\mathrm{C}_{1}\right.$ and $\mathrm{C}_{2}$ ). On analysing the circuit in Fig.3, the current response at $\mathrm{I}_{\text {out }}$ can be derived, mathematically as given in the following equation.

$$
I_{\text {out }}=\frac{s^{2} g_{m 1} R I_{1}-\frac{s g_{m 1} I_{2}}{C_{2}}+\frac{g_{m 1} g_{m 2} I_{3}}{C_{1} C_{2}}}{s^{2}+\frac{s g_{m 1}}{C_{2}}+\frac{g_{m 1} g_{m 2}}{C_{1} C_{2}}}
$$

From the above equation, it can be found that the circuit of Fig. 3 is capable of realizing various CM filtering functions. But, each of the filtering functions can be synthesized by suitable selection of the current input signal(s) as discussed below.

i. If $\mathrm{I}_{1}=\mathrm{I}_{2}=0$ and $\mathrm{I}_{3}=\mathrm{I}_{\text {in }}$, a LP filter can be obtained.

ii. If $\mathrm{I}_{1}=\mathrm{I}_{3}=0$ and $\mathrm{I}_{2}=\mathrm{I}_{\text {in }}$, a BP filter can be obtained.

iii. If $\mathrm{I}_{2}=\mathrm{I}_{3}=0$ and $\mathrm{I}_{1}=\mathrm{I}_{\text {in }}$, a HP filter can be obtained.

iv. If $\mathrm{I}_{1}=\mathrm{I}_{3}=\mathrm{I}_{\mathrm{in},} \mathrm{I}_{2}=0, \mathrm{~g}_{\mathrm{m} 1} \mathrm{R}=1$, a BR filter can be obtained.

v. If $\mathrm{I}_{1}=\mathrm{I}_{2}=\mathrm{I}_{3}=\mathrm{I}_{\mathrm{in}}$, and $\mathrm{g}_{\mathrm{m} 1} \mathrm{R}=1$, an AP filter can be obtained.

Above discussion conclude that the filter structure shown in Fig. 3 can realizes all five standard CM filtering functions without needing inverted/scaled- input signal(s). Moreover, the expression of filter parameters can be determined as: 


$$
\begin{gathered}
\omega_{0}=\sqrt{\frac{g_{m 1} g_{m 2}}{C_{1} C_{2}}} \\
Q_{0}=\sqrt{\frac{g_{m 2} C_{2}}{g_{m 1} C_{1}}}
\end{gathered}
$$

Where $\omega_{0}$, and $Q_{0}$ are angular pole frequency and quality factor. It is clear from Eq. (5)-(6) that $\mathrm{Q}_{0}$ can also be electronically tuned independent of $\omega_{0}$ by simultaneous variation in both $g_{\mathrm{m} 1}$ and $\mathrm{g}_{\mathrm{m} 2}$. Similarly, $\omega_{0}$ can also be electronically tuned independent of $\mathrm{Q}_{0}$ by varying $\mathrm{g}_{\mathrm{m} 1}$ or $\mathrm{g}_{\mathrm{m} 2}$ while keeping the product of $\mathrm{g}_{\mathrm{m} 1}$ and $\mathrm{g}_{\mathrm{m} 2}$ as constant. Thus, both filter parameters are orthogonal electronically tunable.

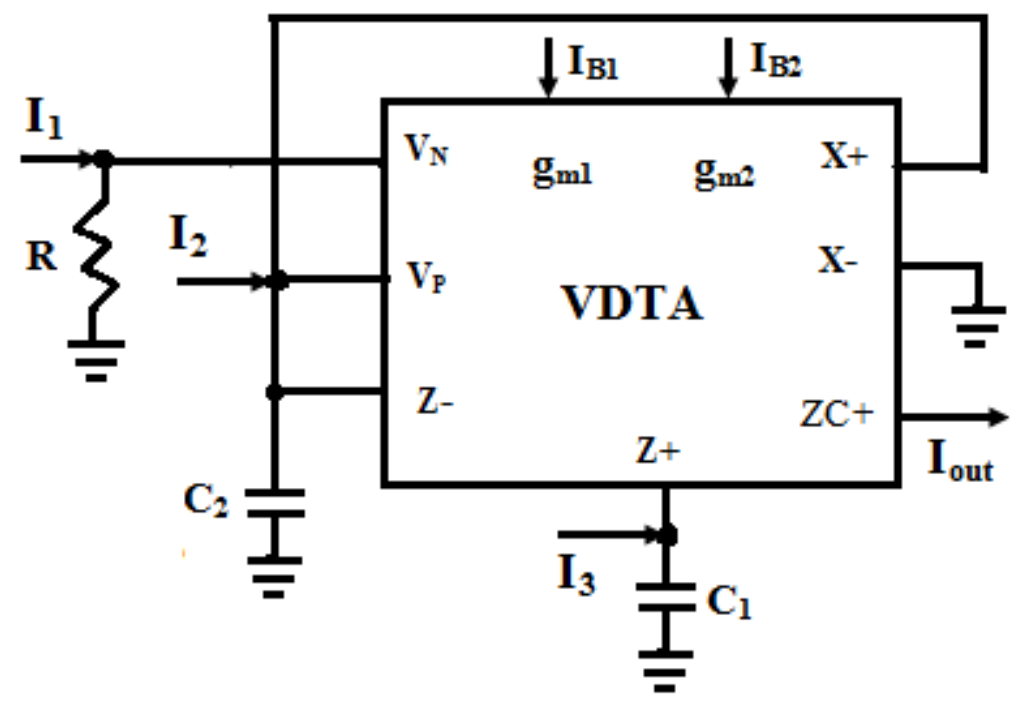

Fig.3. The proposed CM biquad filter

\section{NON IDEAL EFFACTS AND SENSITIVITY ANALYSIS}

To see the effect of non ideal tracking errors of VDTA on the performace of the proposed CM structure, the current-voltage equations of VDTA can be rewritten as:

$$
\left[\begin{array}{c}
I_{Z} \\
I_{Z-} \\
I_{X \pm}
\end{array}\right]=\left[\begin{array}{ccc}
\beta_{1} g_{m 1} & -\beta_{1} g_{m 1} & 0 \\
-\beta_{1} g_{m 1} & \beta_{1} g_{m 1} & 0 \\
0 & 0 & \pm \beta_{2} g_{m 2}
\end{array}\right]\left[\begin{array}{c}
V_{P} \\
V_{N} \\
V_{Z}
\end{array}\right]
$$

Where $\beta_{1}$ and $\beta_{2}$ are the tracking errors of the VDTA and deviated from unit value. The proposed circuit of Fig. 3 have been further reanalysed by taking the above non ideal errors into account. On re-analysing, the nonideal filter transfer functions and its filter parameters can be derived as follow.

$$
\begin{gathered}
I_{\text {out }}=\frac{s^{2} \beta_{1} g_{m 1} R_{1} I_{1}-\frac{s \beta_{1} g_{m 1} I_{2}}{C_{2}}+\frac{\beta_{1} \beta_{2} g_{m 1} g_{m 2} I_{3}}{C_{1} C_{2}}}{s^{2}+\frac{s \beta_{1} g_{m 1}}{C_{2}}+\frac{\beta_{1} \beta_{2} g_{m 1} g_{m 2}}{C_{1} C_{2}}} \\
\omega_{0}=\sqrt{\frac{\beta_{1} \beta_{2} g_{m 1} g_{m 2}}{C_{1} C_{2}}} \\
Q_{0}=\sqrt{\frac{\beta_{2} g_{m 2} C_{2}}{\beta_{1} g_{m 1} C_{1}}}
\end{gathered}
$$

Above equations can conclude that the filter parameters such as pass band gain, $\omega_{0}$ and $\mathrm{Q}_{0}$ may be slightly deviated from ideal ones due to effect of tracking errors of VDTA. Furthermore, the active and passive sensitivities of $\omega_{0}$ and $\mathrm{Q}_{0}$ for the proposed filter in Fig.3 is determined as follow which results in low (with in unity in magnitude) active and passive sensitivities of $\omega_{0}$ and $Q_{0}$. 


$$
\begin{aligned}
& S_{\beta_{1}, \beta_{2}, g_{m 1}, g_{m 2}}^{\omega_{0}}=\frac{1}{2}, S_{C_{1}, C_{2}}^{\omega_{0}}=-\frac{1}{2} \\
& S_{\beta_{2}, g_{m 2}, C_{2}}^{Q_{0}}=\frac{1}{2}, S_{\beta_{1}, g_{m 1}, C_{1}}^{Q_{0}}=-\frac{1}{2}
\end{aligned}
$$

\section{Simulation ResultS}

In order to check the performance, the presented filter shown in Fig. 3 was implemented using CMOS realization of VDTA (as shown in Fig. 2) with transistors W/L ratio calculated as given in Table. II and simulations were made using PSPICE along with $0.18 \mu \mathrm{m}$ CMOS process parameters from TSMC. To design the proposed filter of pole frequency of $3.93 \mathrm{MHz}$ at $\mathrm{Q}_{0}=1$, the circuit was set with biasing voltage of $\mathrm{V}_{\mathrm{DD}}=-\mathrm{V}_{\mathrm{SS}}=$ $1.5 \mathrm{~V}$ and the biasing currents were chosen so that $\mathrm{g}_{\mathrm{m} 1}=\mathrm{g}_{\mathrm{m} 2} \approx 496.2 \mu \mathrm{A} / \mathrm{V} \quad\left(\mathrm{I}_{\mathrm{B} 1}=\mathrm{I}_{\mathrm{B} 2}=53 \mu \mathrm{A}\right)$. The passive components value were calculated as $\mathrm{R}=2 \mathrm{~K} \Omega, \mathrm{C}_{1}=\mathrm{C}_{2}=20 \mathrm{pF}$. Fig. 4 shows the simulated versus ideal current gain responses of LP, HP, BP, and BR for the proposed biquad filter of Fig. 3. The simulated gain responses given in Fig. 4 show good agreement with ideal responses. The total power consumption of the filter was obtained as $1.41 \mathrm{~mW}$. With the same component value setting, the simulated gain and phase response of AP filters are also depicted in Fig. 5.

Further simulations to prove the electronic tuning capability of $\omega_{0}$ independent of $\mathrm{Q}_{0}$ for the proposed circuit were also done. For this purpose, various BP responses at different set of $\mathrm{g}_{\mathrm{m} 1}=\mathrm{g}_{\mathrm{m} 2}=304.82 \mu \mathrm{A} / \mathrm{V}$, $496.2 \mu \mathrm{A} / \mathrm{V}, 681.6 \mu \mathrm{A} / \mathrm{V}, 963.9 \mu \mathrm{A} / \mathrm{V}$ (by simultaneously variations in $\mathrm{g}_{\mathrm{m} 1}$ and $\mathrm{g}_{\mathrm{m} 2}$ ) are plotted in Fig. 6 which result in pole frequency $\left(\mathrm{f}_{0}\right)$ variations of the circuit as $2.30 \mathrm{MHz}, 3.93 \mathrm{MHz}, 5.6 \mathrm{MHz}$, and $8.10 \mathrm{MHz}$ without changing $\mathrm{Q}_{0}(=1)$. Similarly, the simulation results showing the tuning feature of $\mathrm{Q}_{0}$ independent of $\omega_{0}$ for the circuit is also shown in Fig. 7 which were obtained by maintaining the product of $g_{\mathrm{m} 1}$ and $\mathrm{g}_{\mathrm{m} 2}$ to be a constant as $\left(\mathrm{I}_{\mathrm{B} 1}=93.3 \mu \mathrm{A}, \mathrm{I}_{\mathrm{B} 2}=30 \mu \mathrm{A}\right),\left(\mathrm{I}_{\mathrm{B} 1}=70 \mu \mathrm{A}, \mathrm{I}_{\mathrm{B} 2}=40 \mu \mathrm{A}\right),\left(\mathrm{I}_{\mathrm{B} 1}=53 \mu \mathrm{A}, \mathrm{I}_{\mathrm{B} 2}=53 \mu \mathrm{A}\right)$, and $\left(\mathrm{I}_{\mathrm{B} 1}=40 \mu \mathrm{A}, \mathrm{I}_{\mathrm{B} 2}=70 \mu \mathrm{A}\right)$ resulting $\mathrm{Q}_{0}=0.72,0.83,1$, and 1.16 respectively, at constant pole frequency of $3.93 \mathrm{MHz}$.

The transient behavior of the proposed CM circuit is also investigated by applying an input sinusoidal current signal at $\mathrm{f}_{0}=500 \mathrm{KHz}$ with peak to peak amplitude of $80 \mu \mathrm{A}$ and measuring the output at LP filtering response (when $\mathrm{I}_{1}=\mathrm{I}_{2}=0$ and $\mathrm{I}_{3}=\mathrm{I}_{\text {in }}$ ). Fig. 8 shows the corresponding transient behavior of the LP output signal. The percentage of total harmonic distortion of Fig. 8 is 1.67. The dependence of the output harmonic distortion of LP current output on varying frequency in the range of $500 \mathrm{KHz}$ to $4500 \mathrm{KHz}$ of sinusoidal current input signal at constant peak to peak amplitude of $40 \mu \mathrm{A}$ is illustrated in Figure 9 which results the THDs within $3 \%$ acceptable limits.

Further to observe the effect of passive component mismatching on the filter's performance, Monte-Carlo analysis has been performed. To measure the impact, the CM BP output was simulated with 10\% Gaussian deviation in $\mathrm{C}_{1}=\mathrm{C}_{2}=20 \mathrm{pF}$ for 500 concurrently runs. Corresponding simulated results of BP response are shown in Fig.10. Fig. 10a, shows the magnitude response whereas Fig.10b shows the statistical results in the form of histogram where the simulated mean, median and standard deviation were obtained as $4.17 \mathrm{MHz}$, $4.17 \mathrm{MHz}$ and $160.009 \mathrm{KHz}$, respectively which conclude that with respect to the simulated pole frequency of $3.93 \mathrm{MHz}$, the proposed filter is less sensitive to the change in capacitive value and thus offers good passive sensitivity of the circuit. 


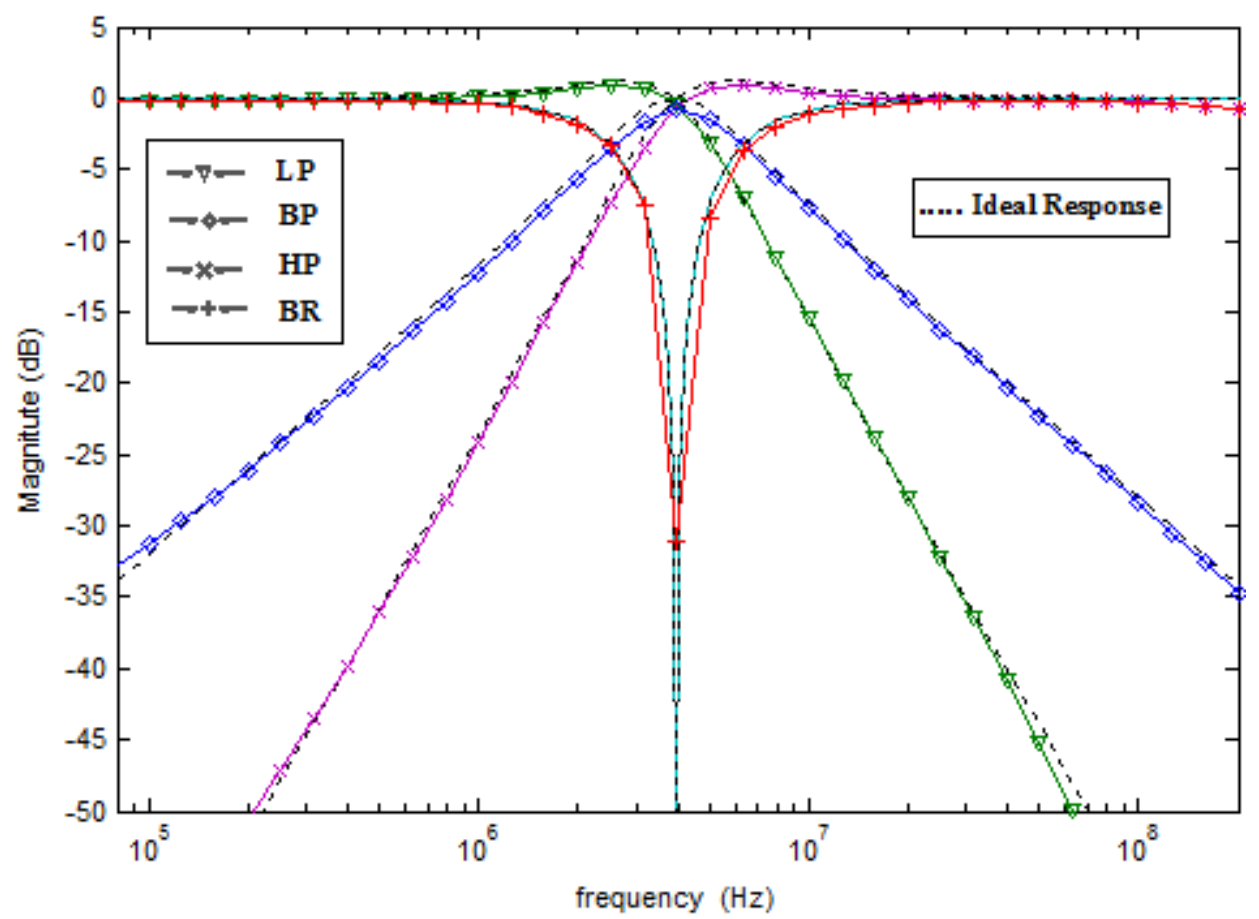

Fig.4. Ideal and PSPICE simulated response of LP, HP, BP, and BR CM Filter

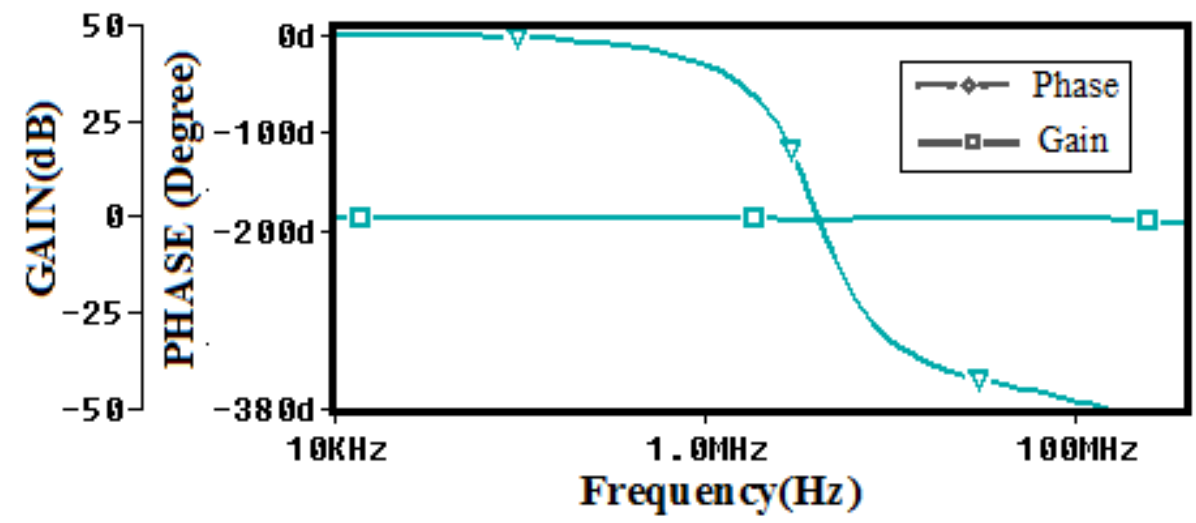

Fig.5. Gain and phase response of AP filter

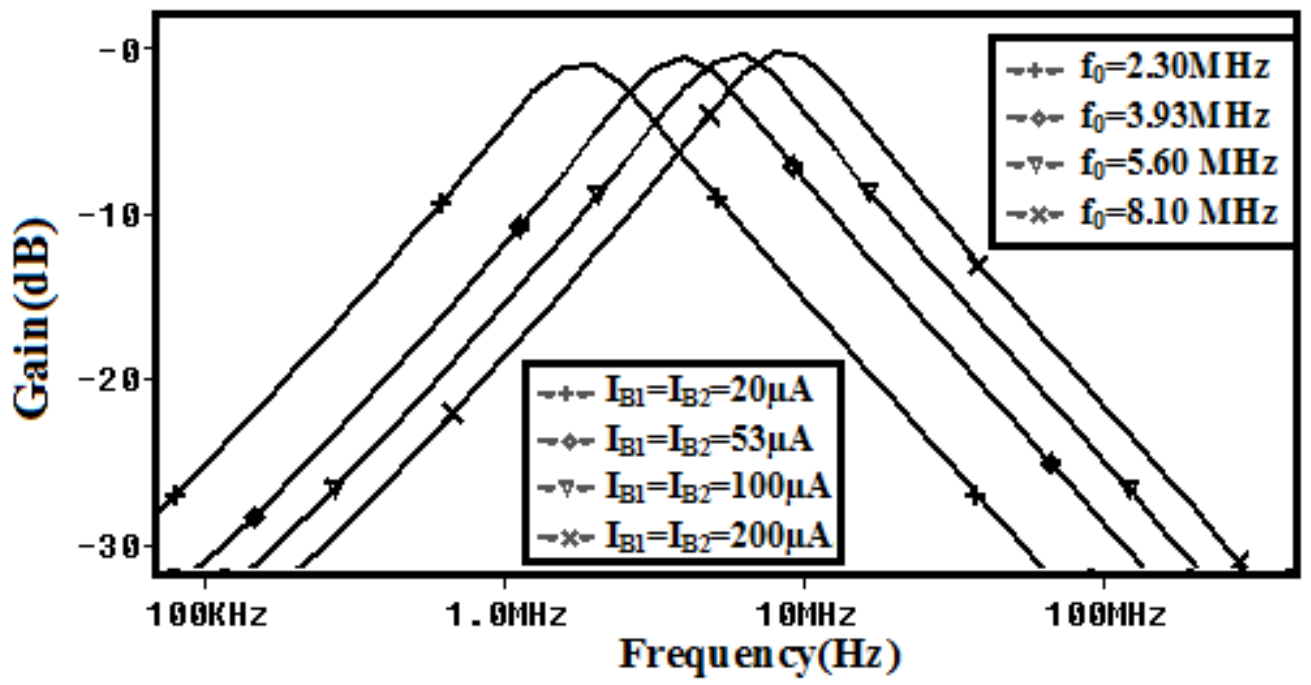

Fig. 6. Simulation results showing electronic tunability of $f_{0}$ independent of $Q_{0}$. 


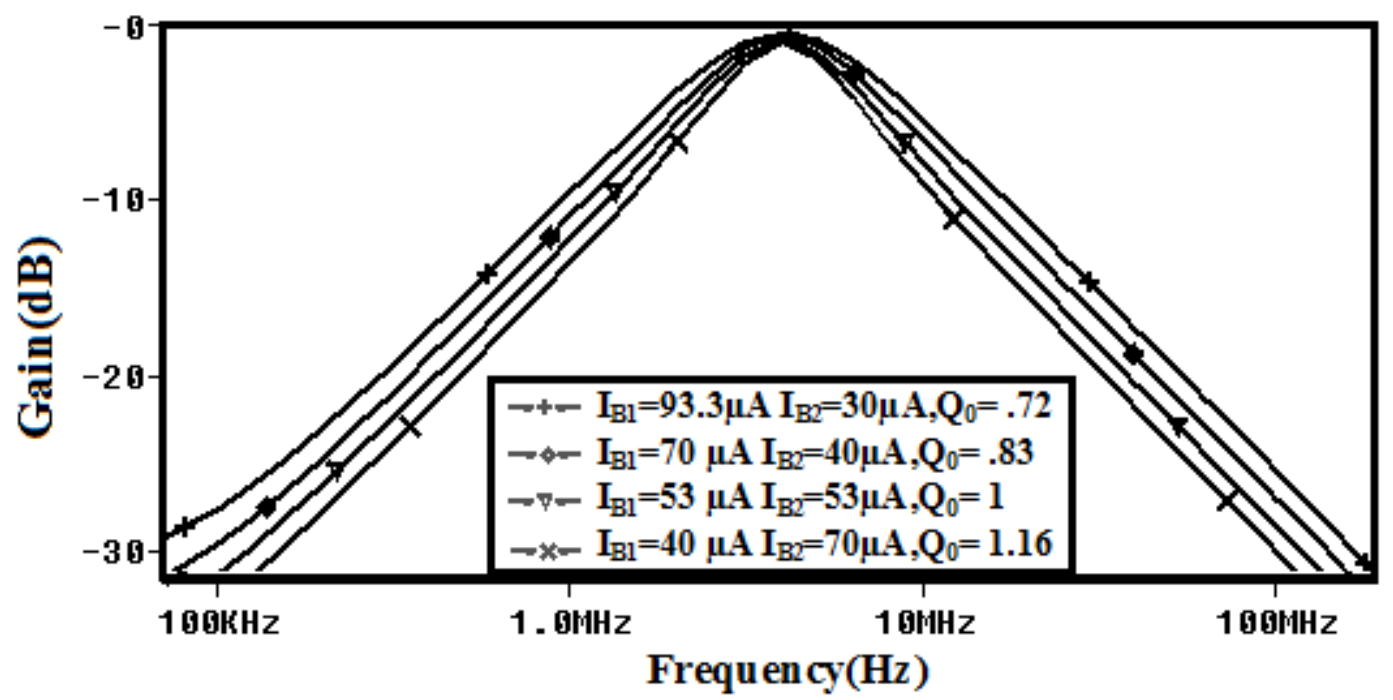

Fig. 7. Simulation results showing electronic tunability of $Q_{0}$ independent of $f_{0}$.

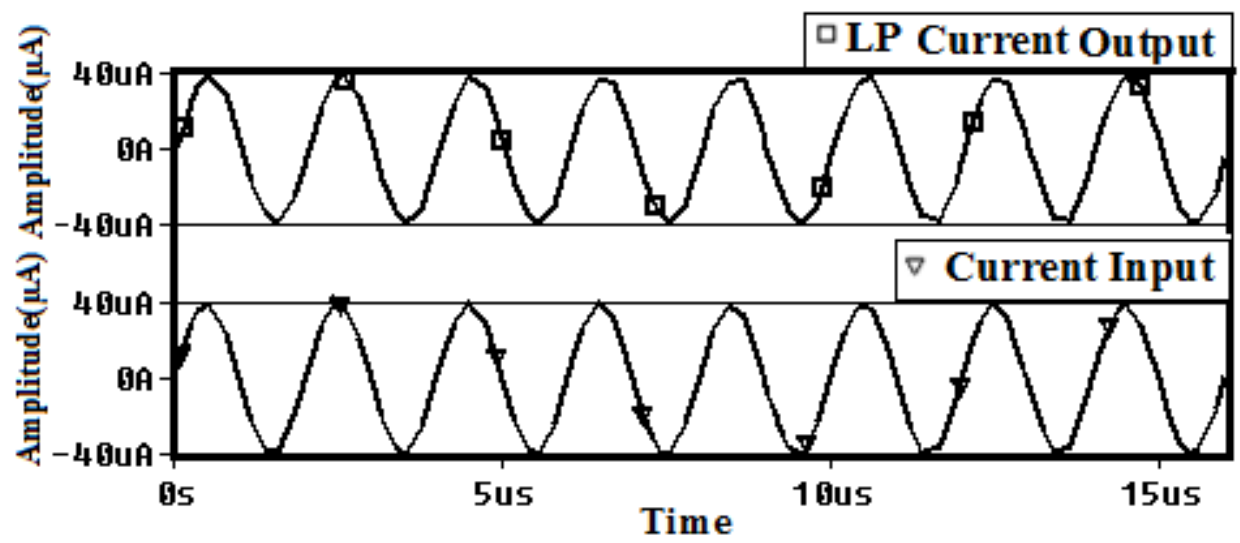

Fig.8. Transient response of LP filter

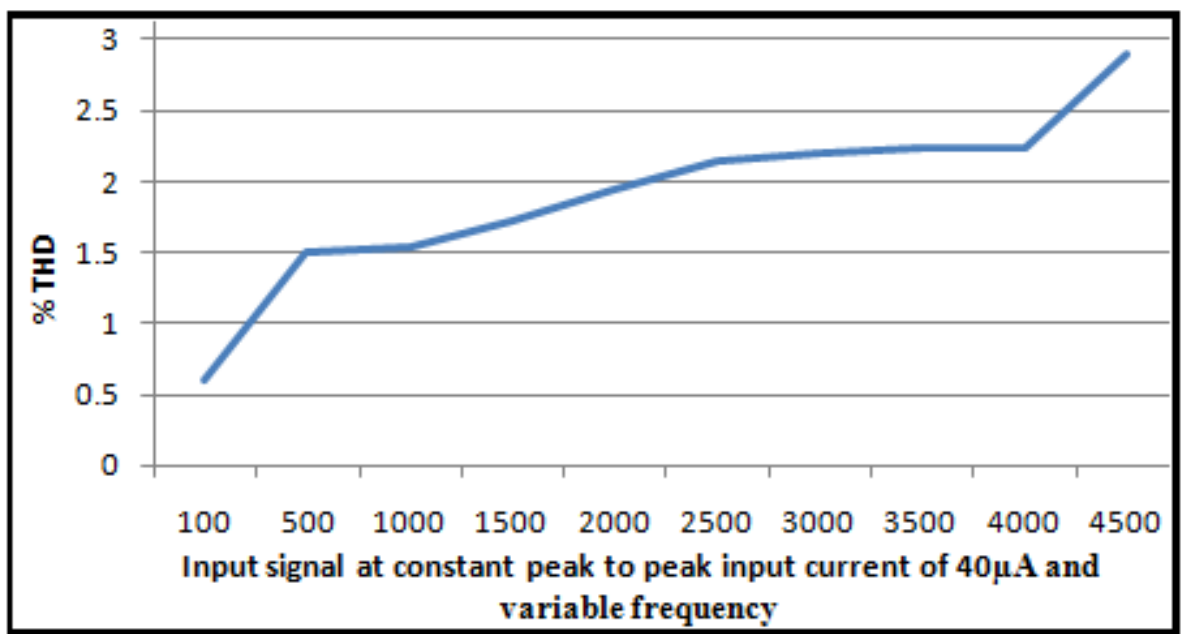

Fig. 9. \% THDs of LP filter at constant peak to peak input current of $40 \mu \mathrm{A}$ and variable frequency 


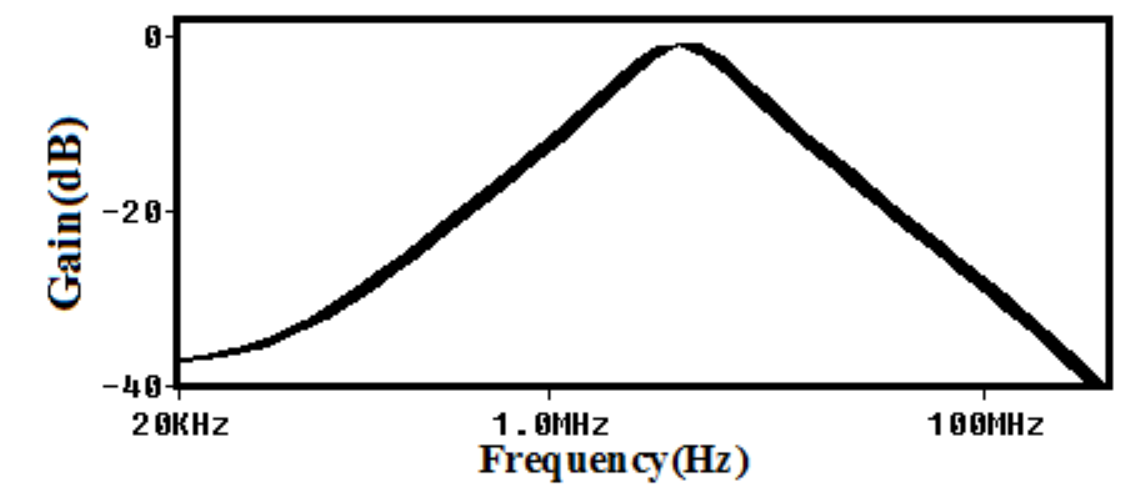

(a)

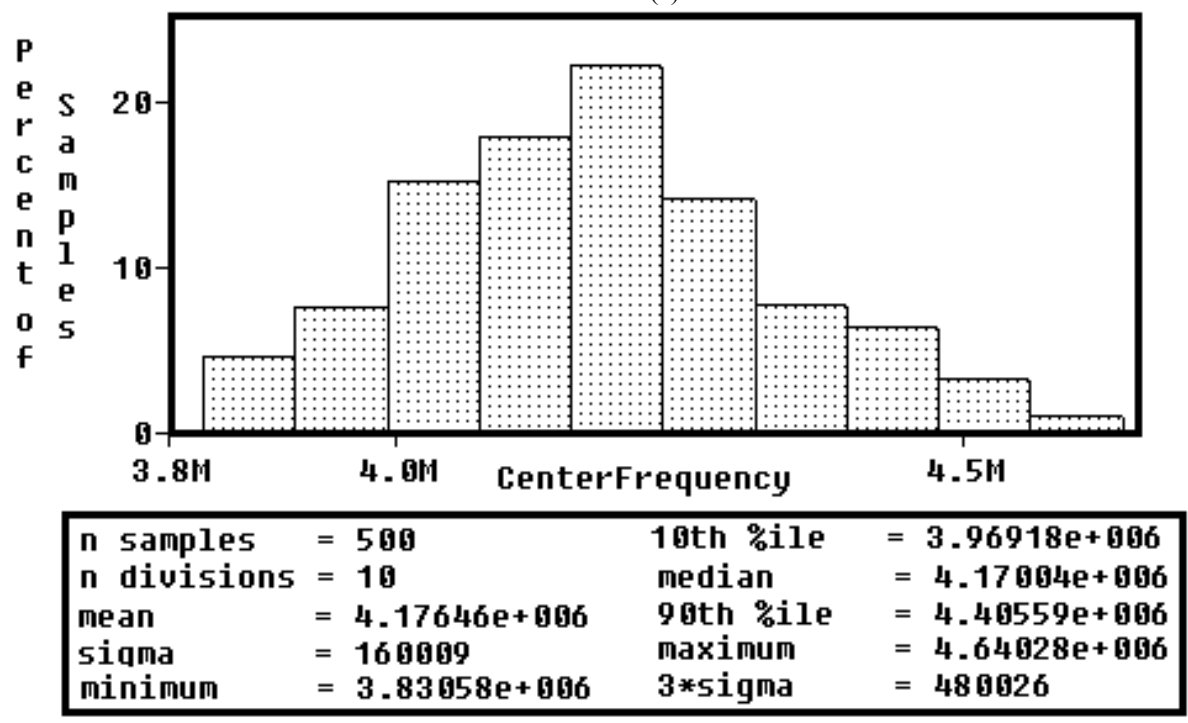

(b)

Fig.10.(a,b) Monte Carlo analysis of CM biquad filter

TABLE II. : TRANSISTORS ASPECT RATIOS OF CMOS IMPLEMENTATION OF VDTA OF FIG.3

\begin{tabular}{|c|c|}
\hline Transistors & $\mathbf{W}(\boldsymbol{\mu m}) / \mathbf{L}(\boldsymbol{\mu m})$ \\
\hline M1-M2,M17-M18 & $8.28 / 0.36$ \\
M3-M4, M11-M16, M24-M30 & $4.32 / 0.36$ \\
M5-M10,M19-23 & $3.6 / 0.36$ \\
\hline
\end{tabular}

\section{CONCLUSION}

A new three input single output CM biquad universal filter based on single active element has been proposed in this paper which also consits of only three grounded passive elements and can realizes all five filtering functions such as LP, BP, HP, BR and AP. To prove the workability of the proposed biquad filter in all aspect, extensive PSPICE simulation results are also made. In addition, the proposed circuit has also number of the benefits as discussed below.

i. Requiring no inverted type and/or scaled type current input signal(s) to realize any filtering functions.

ii. Using only grounded passive elements which make the circuit suitable for IC fabrication point of view.

iii. Using only minimum number of active element.

iv. Exhibiting low active and passive sensitivities.

v. Consuming low power of $1.41 \mathrm{~mW}$.

vi. Providing orthogonal current tuning capability tunability of filter parameters.

vii. Providing the canonical structure as it requires only two grounded capacitors.

\section{REFERENCES}

[1] S.Özcan, H.Kuntman, and O.Çiçekoglu, "A novel multiinput single-output filter with reduced number of passive elements using single current conveyor," In Proceedings of the 43rd IEEE Midwest Symposium on Circuits and Systems. Lansing (MI, USA), pp.1030 $1032,2000$.

[2] A.Ü. Keskin, D.Biolek, E .Hancioglu, and V.Biolkova, "Current-mode KHN filter employing current differencing transconductance amplifiers," International Journal of Electronics and Communications (AEÜ) vol.60,pp. 443-446, 2006.

[3] S.V.Singh, S. Maheshwari, "Current-processing current controlled universal biquad filter,"Radioengineering Journal, vol. 21, no. 1, pp. 317-323, 2012. 
[4] J.Satansup and W.Tangsrirat, "Single input five output electronically tunable current-mode biquad consisting of only ZC-CFTAs and grounded capacitors,"Radioengineering Journal, vol.20, pp. 273-280, 2011.

[5] W. Tangsrirat," Single input three output electronically tunable universal current-mode filter using current follower transconductance amplifiers," Int'l Journal of Electronics and communication (AEU), vol. 65, pp. 783-787, 2011.

[6] R. S.Tomar, S. V Singh, and D. S. Chauhan, "Cascadable low voltage operated current-mode universal biquad filter,"WSEAS Transactions on Signal Processing, vol. 10, pp. 345-353, 2014.

[7] S. V. Singh, S. Maheshwari and D. S. Chauhan, "Universal current-controlled current-mode biquad filter employing MO-CCCCTAs and grounded capacitors," Int'1 J. Circuits and Systems, USA, vol. 1, pp. 35-40, 2010.

[8] R. S. Tomar, S. V. Singh, and D. S. Chauhan, "Current processing current tunable universal biquad filter employing two CCTAs and two grounded," Int'l J. Circuits and Systems, USA, vol. 4, pp. 443-450, 2013.

[9] S. V.Singh, R. S.Tomar, D. S. Chauhan, "Single MO-CFTA based current-mode SITO biquad filter with electronic tuning," Int'1 Journal of Computer Science and Information Security, vol. 11, no. 4, pp. 77-81, 2013.

[10] J.Satansup, W.Tangsrirat, "Single VDTA-based current-mode electronically tunable multifunction filter," in proceedings of the ISEEC 2012, petchburi , pp. 266-272, 2012.

[11] F.Kacar, H.Kuntman, "New current-mode filters using single FDCCII with grounded resistor and capacitors," The Online Journal on Electronics and Electrical Engineering (OJEEE), vol. 2, no. 4, pp. 341-345.

[12] B.Chaturvedi, S.Maheshwari "Current-mode Biquad filter with minimum component count," Active and Passive Electronic Components, pp. 1-7, 2011.

[13] D.Prasad, D. R. Bhaskar, M.Srivastava, "Universal current-mode biquad filter using a VDTA,"Journal of Circuits and Systems, vol. 4, pp. 32-36, 2013.

[14] D.Prasad, D. R. Bhaskar, A. K.Singh,” Universal current-mode biquad filter using dual output current differencing transconductance amplifier," Int'l Journal of Electronics and communication (AEU), vol. 63, pp. 497-501, 2009.

[15] W.Tangsrirat, "Novel current-mode and voltage-mode universal biquad filters using single CFTA," Indian Journal of Engineering \& Material sciences, vol. 17, pp. 99-104, 2010.

[16] N.Herencsar, J.Koton, K.Vrba, "Single CCTA-based universal biquadratic filters employing minimum components," Int'l Journal of Computer and Electrical Engineering, vol. 1, pp. 307-310, 2009.

[17] D.Biolek, V.Biolkova, Z.Kolka, “Current-mode biquad employing CDTA," Indian Journal of. Pure and Applied Physics, vol. 47, pp. 535-537, 2009.

[18] E.Yuce, B.Metin, O.Cicekoglu, "Current-mode Biquadretic filters using single CCII and minimum number of passive elements. Frequenz: Journal Of RF-Engineering and Telecommunication, vol. 58, pp. 225-227, 2004.

[19] S.Mangkalakecree, D. Duangmalai, M.Siripruchyanun, "Current-mode KHN filter using single CC-CCTA," In the Seventh PSU Engineering Conference, pp. 306-309,2009.

[20] C. M.Chang, T. H.Huang, S. H .Tu, C. L.Hou, J. W. Horng, "Universal active current filter using single second-generation current controlled conveyor,” Int’l Journal of Circuits, Systems and Signal Processing, vol. 1, pp. 194-198, 2007.

[21] J.Sirirat, D.Prasetsom, W. Tangsrirat, "High-output-impedance current-mode electronically tunable universal filter using single CFTA,” In proceedings of the ISCIT 2010, Tokyo, Japanypetchburi, pp. 200-203, 2010.

[22] J.Satansup, W.Tangsrirat, "Compact VDTA-based current-mode electronically tunable universal filters using grounded capacitors," Microelectronics Journal, vol. 45, pp. 613-618, 2014.

[23] E.Arsian, , B. Metin, O .Ciekoglu," Multi-input single-output cascadable current-mode universal filter topology with a single current conveyor," Third IASTED international Conference Circuits, Signals, and Systems, pp. 62-66, 2006.

[24] F.Kacar, A. Yesil, H.Kuntman, "Current-mode biquad filters employing single FDCCII. Radioengineering journal , vol. 21, ppp.1269$1278,2012$.

[25] S. V. Singh, S. Maheshwari, D. S. Chauhan, "Electronically tunable current-mode SIMO/MISO universal biquad filter using MOCCCCTAs," International J. of Recent Trends in Engineering and Technology, vol. 3, pp. 65-70, 2010.

[26] C. Shankar and S. V. Singh, "A new trans-admittance-mode biquad filter using MO-VDTAs," WSEAS Transactions on Circuits and Systems, Vol. 14, pp. 8-18, 2015.

[27] C. Shankar and S. V. Singh, "Single VDTA based multifunction trans-admittance-mode biquad filter," Int"l J. of Engineering and Technology, vol. 7, no. 6, pp. 2180-2188, Jan 2016.

[28] J. Satansup, T. Pukkalanun, and W. Tangsrirat, " Electronically tunable single-input five output voltage-mode universal filter using VDTAs and grounded passive elements," Circuits Syst Signal Process, 2012.

[29] G. Gupta, S. V. Singh and S. V. Bhooshan, "VDTA based electronically tunable voltage-mode and transadmittance biquad filter," Int'l J. Circuits and Systems, USA, vol. 6, pp. 93-102, 2015.

\section{AUTHOR PROFILE}

Chandra Shankar was born in Etawah, India. He received his B.Tech degree in Electronics and Communication from GLAITM, Mathura (India), M.Tech. degree from CDAC, Mohali (India) and Pursuing $\mathrm{Ph} . \mathrm{D}$ from Jaypee Institute of Information Technology, Noida (India). He is working as an Asst. Professor in the Dept. of Electronics of JSS Academy of Technical Education Noida, (India). His area of interest is Analog Signal Processing and Circuit Designing.

Dr. Sajai Vir Singh was born in Agra, India. He received his B.E. degree in Electronics and Telecommunication from NIT Silchar, Assam (India), M.E. degree from MNIT Jaipur, Rajasthan (India) and Ph.D. degree from Uttarakhand Technical University. He is currently working as Associate Professor in the Department of Electronics and Communication Engineering of Jaypee Institute of Information Technology, Noida (India) and has been engaged in teaching and design of courses related to the design and synthesis of Analog and Digital Electronic Circuits. He served as the reviewer of number of technical Int'l Journals like Micro electronics Journal, Active and Passive Electronic components, Circuits and Systems etc. He also served as the member of Technical Program Committee as well as session chair in number of IEEE Int'l Conferences. His research areas include Low Power CMOS Circuit Design, Digital and Analog CMOS Design, Current Mode Active Circuits Design and SRAM Memory Design. He has published approximately 50 numbers of papers in various International Journals/Conferences. 